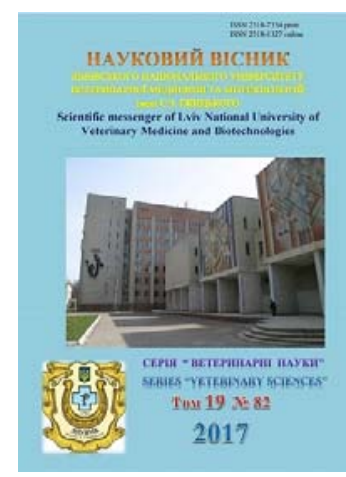

Науковий вісник Львівського національного університету ветеринарної медицини та біотехнологій імені С.З. Гжицького

Scientific Messenger of Lviv National University of Veterinary Medicine and Biotechnologies

doi:10.15421/nvlvet8212

ISSN 2518-7554 print

ISSN 2518-1327 online

$\underline{\text { http://nvlvet.com.ua/ }}$

УДК 619:616.993.1:636.4

\title{
Антиінтерферонова й антилактоферинова активність мікроорганізмів дистального відділу кишечника поросят за змішаної нематодозно-протозоозної інвазії
}

\author{
Р.А. Пеленьо \\ andriyovich30@ukr.net \\ Львівський національний університет ветеринарної медицини та біотехнологій імені С.3. Гюицького, \\ вул. Пекарська, 50, м. Львів, 79010, Украӥна
}

Вивчено зміни антиінтерфероновової й антилактоферинової активності мікроорганізмів дистального відділу кишечнику поросят за змішаної нематодозно-протозоозної інвазії. Встановлено, що інвазія організму асоціацією аскарисів, балантидій та еймерій не впливає на антиінтерферонову активність мікроорганізмів роду Bacteroides spp., Prevotella spp., Propionibacterium spp., Peptostreptococcus spp. i Fusobacterium spp., npome nidвuщyє iï y Bifidobacterium spp. на 9,09\% $i$ Clostridium spp. - на 22,22\%, та знижує на 7,69\% у Eubacterium spp. Порівняно із контролем, антиінтерферонова активність мікроорганізмів, виділених із кишечнику тварин дослідної групи, була вищою у Citrobacter spp., Staphylococcus spp., Klebsiella spp. i Streptococcus spp. відповідно в 4,6, 4,5, 2,9 ma 2,3 раза. У E. coli лакт. «-» гем «+» та E. coli лакт. «+» гем «-» i Enterococcus spp. зростання досліджуваного показника становило від 1,2 до 1,4 раза. У результаті дослідження антилактоферинової активності облігатних анаеробів, виділених із дистального відділу кишечника поросят, інвазованих асоиіацією кишкових паразитів, установлено ї̈ зростання в мікроорганізмів роду Bifidobacterium spp. i Bacteroides spp. на 33,3\%, Prevotella spp. - на 29,2\%, Clostridium spp. - на 64,0\%, Eubacterium spp. - на 26,7\%, Propionibacterium spp. - на 84,6\% $i$ Peptostreptococcus spp. - на 15,4\%, порівняно із мікроорганізмами, виділеними із кишечника агельмінтних поросят. Серед МАФАнМ найбільше, порівняно із контролем, антилактоферинова активність зросла у бактерій роду Citrobacter spp., Klebsiella spp. i Staphylococcus spp. відповідно в 7,8, 3,7 i 3,5 раза. Менш виражене зростання даного показника встановлено y бактерій роду Candida spp. - y 1,5 раза, E. coli лакт. «-» гем «+» i Enterobacter spp. - y 1,4 paза, Lactobacillus spp. $i$ Enterococcus spp. - y 1,3 раза, Streptococcus spp. - y 1,2 раза.

Ключові слова: облігатні анаероби, умовно-патогенна мікрофлора, змішана інвазія, антиінтерферонова активність, антилактоферинова активність.

\section{Антиинтерфероновая и антилактофериновая активность микроорганизмов дистального отдела кишечника поросят при смешанной нематодозно-протозоозной инвазии}

\author{
Р.А. Пеленьо \\ andriyovich30@ukr.net
}

\begin{abstract}
Львовский национальный университет ветеринарной медицины и биотехнологий имени С.3. Гжицкого, ул. Пекарская, 50, г. Львов, 79010, Украина
\end{abstract}

Изучены изменения антиинтерфероновой и антилактофериновой активности микроорганизмов дистального отдела кишечника поросят при смешанной нематодозно-протозоозной инвазии. Установлено, что кишечные паразиты не влияют на антиинтерфероновую активность Bacteroides spp., Prevotella spp., Propionibacterium spp., Peptostreptococcus spp. $i$

Citation:

Peleno, R.A. (2017). Antiinterfearonic and antilactofearinic activity of microorganisms of distal part of the pigs intestine. Scientific Messenger LNUVMB, 19(82), 56-60. 
Fusobacterium spp., повышают её в Bifidobacterium spp. i Clostridium spp. соответственно на 9,09\% и 22,22\% и снижают на 7,69\% в Eubacterium spр. По сравнению с контролем, у животных опытной группы антиинтерфероновая активность возросла в Citrobacter spp. u Staphylococcus spp. в 4,6 и 4,5 раза, Klebsiella spp. и Streptococcus spp. coответственно в 2,9 и 2,3 раза, а также от 1,2 до 1,4 раза активность возросла в E. coli лакт. «-» гем «+», E. солі лакт. «+» гем «-» и Enterococcus spp. При действии кишечных паразитов возрастает, по сравнению с агельминтными поросятами, АЛфА у Bifidobacterium spp. и Bacteroides spp. на 33,3\%, Prevotella spp. - на 29,2\%, Clostridium spp. - на 64,0\%, Eubacterium spp. - на 26,7\%, Propionibacterium spp. - на 84,6\% и Pерtostreptococcus spp. - на 15,4\%. Среди МАФАнМ, изолированньх от инвазированых животных, антилактофериновая активность выросла в Citrobacter spp., Klebsiella spp. u Staphylococcus spp. coответственно в 7,8, 3,7 и 3,5 раза. У Candida spp. исследуемьй показатель вырос в 1,5 раза, E. соli лакт. «-» гем «+» и Enterobacter spp. - в 1,4, Lactobacillus spp. u Enterococcus spp. - в 1,3 и Streptococcus spp. - 8 1,2 paзa.

Ключевые слова: облигатные анаэробы, условно-патогенная микрофлора, смешанная инвазия, антиинтерфероновая активность, антилактофериновая активность.

\title{
Antiinterfearonic and antilactofearinic activity of microorganisms of distal part of the pigs intestine
}

\author{
R.A. Peleno \\ andriyovich30@ukr.net

\begin{abstract}
Stepan Gzhytskyi National University of Veterinary Medicine and Biotechnologies Lviv,
\end{abstract} \\ Pekarska Str., 50, Lviv, 79010, Ukraine
}

\begin{abstract}
It was investigated the changes of anti infearonic and anti lactofearinic activity of microorganisms of distal part of the pigs intestine for mixed nonmatodozic - protozoozic invasion. Established that the organism invasion of the ascaris association, balantidium and eymeria does not cause changes of anti infearonic activity in microorganisms of genus Bacteroides spp., Prevotella spp., Propionibacterium spp., Peptostreptococcus spp. and Fusobacterium spp., but increases it in Bifidobacterium spp. at $9.09 \%$ and Clostridium spp. at $22.22 \%$, and decreases to $7.69 \%$ in Eubacterium spp. Compared with controls, infearonic activity of microorganisms selected from animals intestine from the 2nd group was higher in Citrobacter spp., Staphylococcus spp., Klebsiella spp. and Streptococcus spp. accordingly in 4.6, 4.5, 2.9 and 2.3 times. In colilact. «-» gem "-» and Enterococcus spp. the growth of investigated rate was 1.2 to 1.4 times. Thanks to the result of investigation of anti infearonic activity of obligate anaerobes selected from the distal intestine of pigs infested by the association of intestinal parasites, was set its growth in microorganisms of genus Bifidobacterium spp. and Bacteroides spp. to 33.3\%, Prevotella spp. - to 29.2\%, Clostridium spp. - to 64.0\%, Eubacterium spp. - to 26.7\%, Propionibacterium spp. - to 84.6\% and Peptostreptococcus spp. - to 15.4\%, compared with microorganisms selected from the intestines of agility pigs. Among MAFAnM the most compared, to control, anti lactofearinic activity was grown in bacteria of genus Citrobacter spp., Klebsiella spp. and Staphylococcus spp. accordingly in 7.8, 3.7 and 3.5 times. Less expressed growth of the indicator was found in bacteria of genus Candidaspp. - into 1.5 times, E. coli.lact. «-» gem «+» and Enterobacter spp. - 1.4 times, Lactobacillusspp. and Enterococcus spp. -1.3 times and Streptococcus spp. -1.2 times.
\end{abstract}

Key words: obligate anaerobes, conditionally pathogenic microflora, mixed invasion, anti infearonic activity, anti lactofearinic activity.

\section{Вступ}

Формування симбіотичних відносин популяціями мікроскопічних організмів, які населяють тіло тварин, сприяє утворенню специфічного «мікросимбіоценозу» $з$ відкритою саморегульованою системою мікроорганізмів автохтонних і алохтонних видів, які перебувають у певних взаємозв'язках (Gomes and Malcata, 1999; Buharin, 1999; Buharin et al., 2005; Morozova, 2013). Унікальною моделлю для вивчення міжпопуляційних взаємин є кишечник. Будь-яка зміна структури біоценозу кишечнику призводить до наростання персистуючих властивостей умовно-патогенної та патогенної мікрофлори, інактивації імунного захисту організму господаря і формування осередків хронічної інфекції (Fil'chakov and Zarickij, 2005; Ivanova et al., 2009; Romanova et al., 2011; Holubnycha, 2014).

Крім мікроорганізмів, кишечник заселяють кишкові паразити, що є однією з причин порушень гомеостазу, а також сприятливим чинником для виникнення та розвитку синдрому ендогенної інтоксикації (Kozlov et al., 2010).

Досі залишаються нез'ясованими питання впливу кишкових паразитів і продуктів їхньої життєдіяльнос- ті на основні біологічні властивості представників нормофлори кишечнику. Наслідком цього $є$ відсутність глибокого розуміння патогенезу багатьох хвороб, що своєю чергою унеможливлює розробку нових ефективних засобів боротьби з ними.

Саме тому проведення досліджень, спрямованих на вивчення впливу змішаної нематодознопротозоозної інвазії на біологічні властивості мікроорганізмів кишечнику, є актуальним.

Метою роботи було вивчити влив змішаної протозоозно-нематодозної інвазії на антиінтерферонову й антилактоферинову активність мікроорганізмів, які персистують у дистальному відділі кишечнику поросят.

\section{Матеріал і методи досліджень}

В експериментах in vitro використовували мікроорганізми, виділені з мікробіоценозу дистального відділу кишечнику інтактних поросят, - контрольна група та поросят, уражених змішаною нематодознопротозоозною інвазією (аскариси + еймерії + балантидіï), - дослідна група. При формуванні дослідної групи враховували інтенсивність інвазії (II) гельмін- 
тами та найпростішими, яку визначали методом McMaster (Vasil'eva, 1995). Так, кількість ооцист балантидій в 1 г калу становила 752,9 $\pm 64,7$, еймерій $639,1 \pm 49,4$, яєць аскарисів 626,3 $\pm 26,1$ екземплярів.

Відбір матеріалу для дослідження проводили індивідуально із прямої кишки в стерильні пеніцилінові флакони. Час із моменту забору проб до моменту досліджень не перевищував 2-ох годин.

Для проведення бактеріологічних досліджень наважку калу масою 1 г ретельно розтирали в стерильній ступці з 9 мл стерильного буферного розчину. 3 основного розведення виготовляли ряд таких розведень, починаючи $310^{2}$ і до $10^{12}$. Висів суспензії в кількості 0,05-0,1-1,0 мл робили на Schaedler-arap, ентерококагар, жовтково-сольовий агар, кров'яний агар, вісмут-сульфіт агар, середовища Ендо і Плоскірєва та агар Сабуро.

Посіви факультативних анаеробів культивували в термостаті за $37^{\circ} \mathrm{C}$ протягом 24 годин, облігатні анаероби - протягом 48 годин в анаеробній камері з використанням газогенераторних пакетів «GasPak Anaerobic System» (BBL, CШA).
Фактори персистентності виділених мікроорганізмів визначали згідно з рекомендаціями О.В. Бухарина (Buharin, 1999).

Одержані результати піддавали статистичній обробці, яку проводили методом варіаційної статистики 3 визначенням середніх значень величин і середньої похибки. Вірогідність відмінностей між середніми значеннями під час проведення аналізу оцінювали, використовуючи критерії Стьюдента (t). Відмінність між величинами вважали вірогідною, коли ймовірність різниці становила $\mathrm{P} \leq 0,05$.

\section{Результати та їх обговорення}

Результати дослідження асоціативного впливу аскарисів, еймерій та балантидій на AIA і АЛфА ізольованої нами кишкової мікрофлори поросят показано на рис. $1-4$.

Із одержаних даних видно, що ураження поросят змішаною нематодозно-протозоозною інвазією порізному вплинуло на антиінтерферонову активність облігатних анаеробів, виділених з дистального відділу кишечнику (рис. 1).

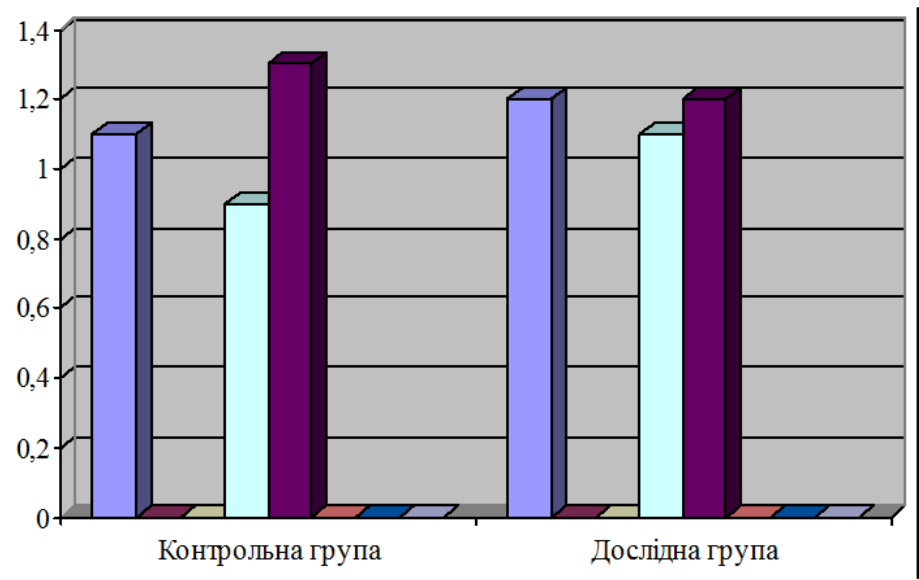

$$
\begin{aligned}
& \square \text { Bifidobacterium spp. } \\
& \square \text { Bacteroides spp. } \\
& \square \text { Prevotella spp. } \\
& \square \text { Clostridium spp. } \\
& \square \text { Eubacterium spp. } \\
& \square \text { Propionibacterium spp. } \\
& \square \text { Peptostreptococcus spp. } \\
& \square \text { Fusobacterium spp. }
\end{aligned}
$$

Рис. 1. Антиінтерферонова активність облігатних анаеробів, виділених дистального відділу кишечнику поросят, Од.

Аналіз результатів показав, що інвазія поросят аскарисами, еймеріями і балантидіями не вплинула на досліджуваний показник таких родів мікроорганізмів, як Bacteroides spp., Prevotella spp., Propionibacterium spp., Peptostreptococcus spp. i Fusobacterium spp. 3pocтання AIA на 9,09\% і 22,22\% встановлено у бактерій роду Bifidobacterium spp. і Clostridium spp., а зниження на 7,69\% - у мікроорганізмів Eubacterium spp. Такі зміни можуть бути наслідком динамічних процесів у мікробіоценозі, сталість якого безперервно порушується наявністю кишкових паразитів, а також різною напруженістю захисних сил організму.

За дії кишкових паразитів змінювалася також АЛфА облігатних анаеробів, виділених із дистального відділу кишечнику поросят (рис. 2). Проте на відміну від AIA, у всіх ізольованих нами мікроорганізмів АЛфА зросла, порівняно із поросятами контрольної групи, у Bifidobacterium spp. i Bacteroides spp. на $33,3 \%$, Prevotella spp. - на 29,2\%, Clostridium spp. - на 64,0\%, Eubacterium spp. - на 26,7\%, Propionibacterium spp. - на 84,6\% і Peptostreptococcus spp. - на 15,4\%.

Стимулювальний вплив кишкових паразитів та продуктів їхньої життєдіяльності на АЛфА мікроорганізмів дистального відділу кишечнику поросят, ймовірно, обумовлений посиленою інактивацією лактоферину, що $є$ регулятором метаболізму заліза в організмі.

Дослідження антиінтерферонової активності МАФАнМ, виділених із дистального відділу кишечника поросят (рис. 3), показало, що вона була притаманна практично всім мікроорганізмам: як тим, що були ізольовані від здорових, так і виділеним від уражених паразитами тварин, крім Lactobacillus spp. і Candida spp. Рівень експресії цієї ознаки у мікроорганізмів, виділених від здорових тварин, перебував у межах від 0,2 до 3,7 ОД, а в уражених асоціацією аскаридиеймерії-балантидії - від 0,9 до 4,3 ОД.

Порівняно із контрольною групою, у тварин дослідної групи AIA зросла найбільше у Citrobacter spp. i Staphylococcus spp. - відповідно в 4,6 і 4,5 раза, дещо 
менше - у Klebsiella spp. і Streptococcus spp., відповідно у 2,9 і 2,3 раза та від 1,2 до 1,4 раза активність зросла у E. coli лакт. «-» гем «+», E. coli лакт. «+»» гем «-» i Enterococcus spp. Одержані нами результати засвідчують, що такий фактор персистенції мікроорганізмів, як AIA, тісно зв'язаний з інвазією організму кишковими паразитами i, певною мірою, може впливати на їі перебіг.

Результати дослідження антилактоферинової активності МАФАнМ, виділених із дистального відділу кишечнику поросят, показано на рис. 4.

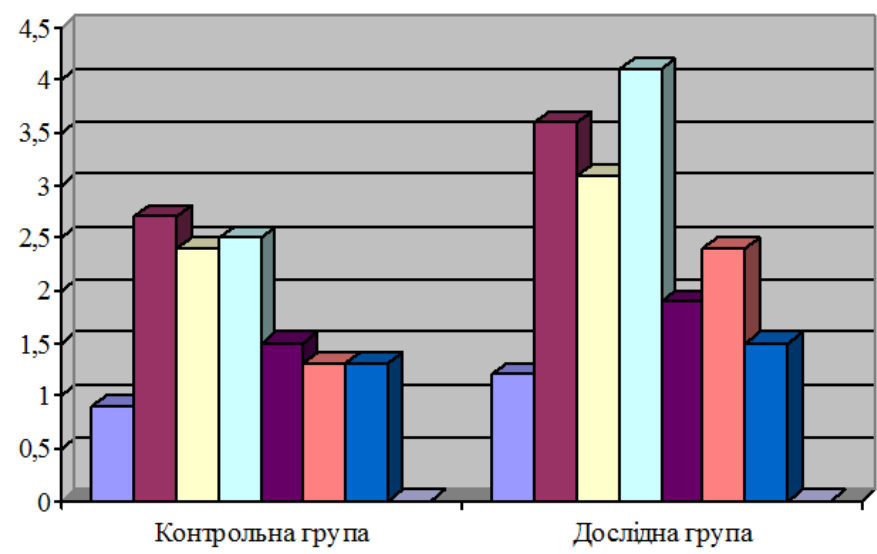

口 Bifidobacterium spp.

$\square$ Bacteroides spp.

$\square$ Prevotella spp.

$\square$ Clostridium spp.

¿ Eubacterium spp.

$\checkmark$ Propion ibacterium spp.

口Peptostreptococcus spp.

口Fusobacterium spp.

Рис. 2. Антилактоферинова активність облігатних анаеробів, виділених із дистального відділу кишечнику поросят, нг/мл

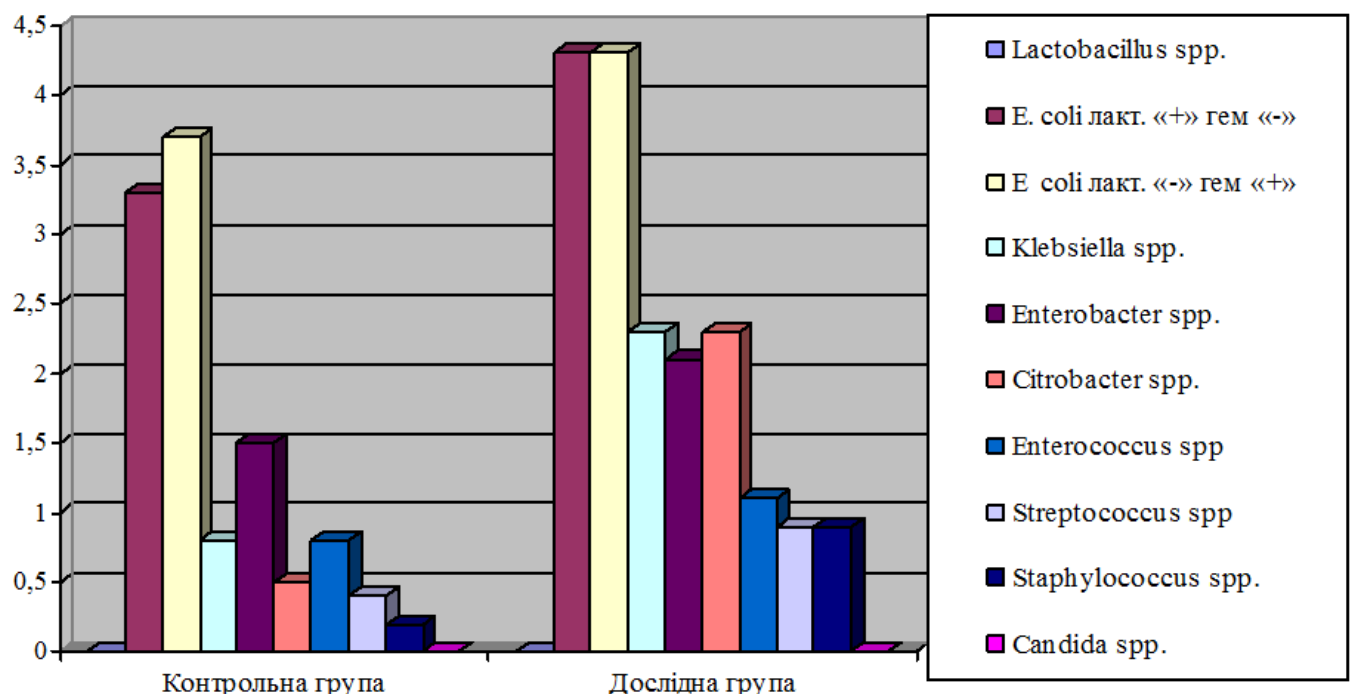

Рис. 3. Антиінтерферонова активність МАФАнМ, виділених із дистального відділу кишечнику поросят, Од.

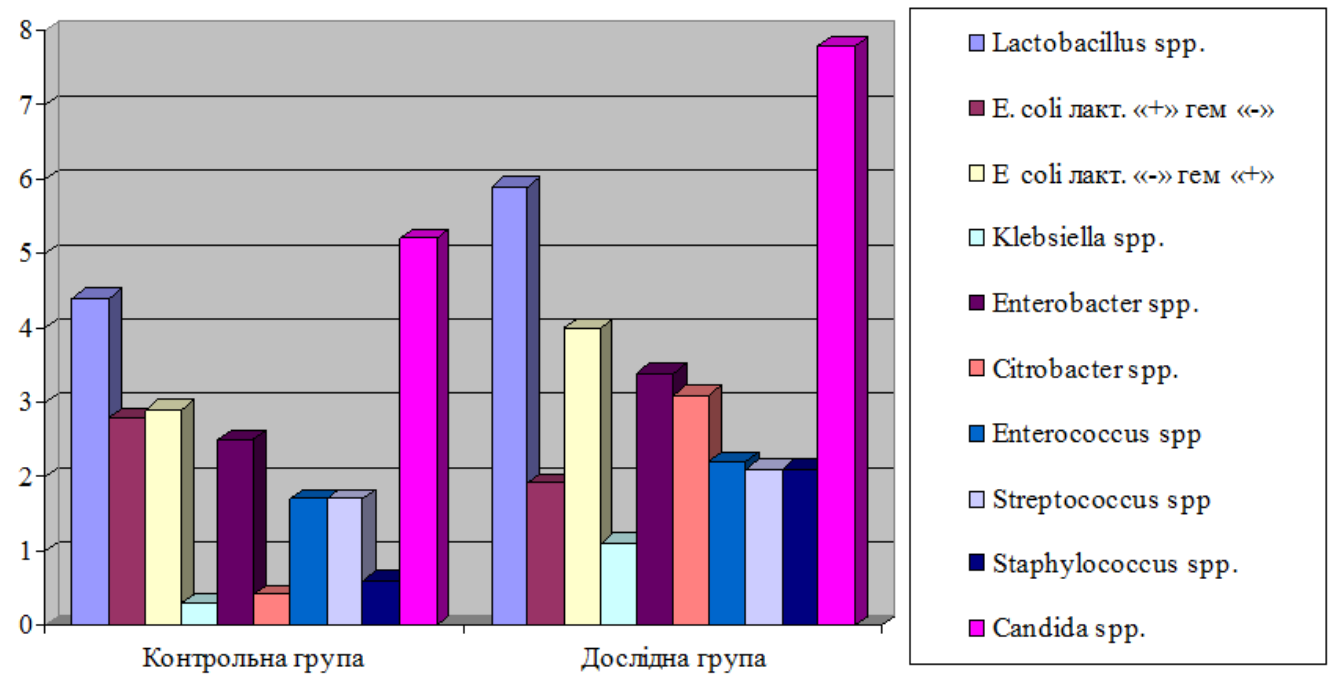

Рис. 4. Антилактоферинова активність МАФАнМ, виділених із дистального відділу кишечнику поросят, нг/мл 
Встановлено, що АЛфА була властива всім МАФАнМ, ізольованим як від інтактних, так і від уражених кишковими паразитами поросят. При цьому рівень експресії АЛфА мікроорганізмів, виділених від поросят контрольної групи, становив від 0,3 до 5,2 нг/мл, а дослідної - від 1,1 до 7,8 нг/мл. Наростання персистенції МАФАнМ встановлено у всіх ізольованих нами мікроорганізмів, крім E. coli лакт. «+» гем «-», у яких активність виявилася нижчою, порівняно iз активністю мікроорганізму, виділеного від інтактних поросят, на 32,1\%. Найбільше антилактоферинова активність зросла у Citrobacter spp., Klebsiella spp. i Staphylococcus spp. - відповідно у 7,8, 3,7 і 3,5 раза, тимчасом як у Candida spp. вона зросла в 1,5 раза, $E$. coli лакт. «-» гем «+» i Enterobacter spp. - у 1,4 раза, Lactobacillus spp. i Enterococcus spp. - y 1,3 paza, Streptococcus spp. - y 1,2 paзa.

\section{Висновки}

1. Ураження поросят змішаною нематодознопротозоозною інвазією за інтенсивності інвазії балантидіями 752,9 $\pm 64,7$ ооцист, еймерій $-639,1 \pm 49,4$ ооцист, аскарисів $626,3 \pm 26,1$ яєць в 1 г калу не впливає на антиінтерферонову активність Bacteroides spp., Prevotella spp., Propionibacterium spp., Peptostreptococcus spp. і Fusobacterium spp., підвищує iii у Bifidobacterium spp. і Clostridium spp. відповідно на 9,09\% і 22,22\%, у Citrobacter spp. і Staphylococcus spp. - у 4,6 i 4,5 paza, Klebsiella spp. i Streptococcus spp. - у 2,9 і 2,3 раза, в E. coli лакт. «-» гем «+», E. coli лакт. «+» гем «-» і Enterococcus spр від 1,2 до 1,4 раза та знижує на 7,69\% у Eubacterium spp., порівняно із контролем.

2. За дії кишкових паразитів встановлено зростання антилактоферинової активності як в облігатних анаеробів, так i серед МАФАнМ. Зокрема у Bifidobacterium spp. і Bacteroides spp. зростання цього показника становило 33,3\%, Prevotella spp. - 29,2\%, Clostridium spp. - 64,0\%, Eubacterium spp. - 26,7\%, Propionibacterium spp. - 84,6\% i Peptostreptococcus spp. - 15,4\%. У Citrobacter spp., Klebsiella spp. i Staphylococcus spp. антилактоферинова активність зросла відповідно у 7,8, 3,7 і 3,5 раза, у Candida spp.в 1,5 раза, E. coli лакт. «-» гем «+» і Enterobacter spp. в 1,4 раза, Lactobacillus spp. і Enterococcus spp. - в
1,3 раза, Streptococcus spp. - в 1,2 раза, порівняно із контролем.

\section{Бібліографічні посилання}

Buharin, O.V. (1999). Persistencija patogennyh bakterij. M. : Medicina, 1999. - 366 s. (in Russian).

Vasil'eva, Z.G. (1995). Metody gel'mintologicheskih issledovanij. M.: Medgiz (in Russian).

Ivanova, E.V., Perunova, N.B., Valyshev, A.V. (2009). Vidovaja harakteristika $\mathrm{i}$ faktory persistencii bifidoflory kishechnika $\mathrm{v}$ norme i pri disbiozah. Zhurnal mikrobiologii. 2, 89-93 (in Russian).

Holubnycha, V.M. (2014). Biolohichni vlastyvosti umovno patohennykh mikroorhanizmiv vydilenykh vid khvorykh na HRVI. Vseukrainska naukovopraktychna konferentsiia «Infektsiini khvoroby V praktytsi likaria-internista: suchasni aspekty», SumDU, 27-29 (in Ukrainian).

Kozlov, S.S., Ahmedova, M. D., Zahidova, N.A. (2010). Sindrom jendogennoj intoksikacii u detej, bol'nyh smeshannymi kishechnymi parazitozami. Medicinskaja parazitologija i parazitarnye bolezni. 1, 17-19 (in Russian).

Buharin, O.V., Gincburg, A.L., Romanova, Ju.M., Jel'Registan, G.I. (2005). Mehanizmy vyzhivanija bakterij. M.: Medicina (in Russian).

Morozova, O.V. (2013). Mikrobnyi faktor u problemi khronizatsii ta persystenizatsii infektsiinoho protsesu. Infektsiini khvoroby. 4, 93-96 (in Ukrainian).

Romanova, Ju.M., Didenko, L.V., Tolordava, Je.R., Gincburg, A.L. (2011). Bioplenki patogennyh bakterij $\mathrm{i}$ ih rol' $\mathrm{v}$ hronizacii infekcionnogo processa. Poisk sredstv bor'by s bioplenkami. Vestn. RAMN. 10, 3139 (in Russian).

Fil'chakov, I.V., Zarickij, A.M. (2005). Persistencija bakterij i formirovanie dominantnyh populjacij vozbuditelja. Suchasni infekciï. 2, 20-27 (in Russian).

Gomes, A.M.P., Malcata, F.X. (1999). Bifidobacterium spp. and Lactobacillus acidophilus: biological, biochemical, technological and therapeutical properties relevant for use as probiotics. Trends in Food Science \& Technology. 10, 139-157.

Guarner, F., Malagelada, J.-R. (2003). Gut flora in health and disease. tl LanceL. 360, 512-519.

Received 19.09.2017

Received in revised form 29.10.2017 Accepted 31.10.2017 